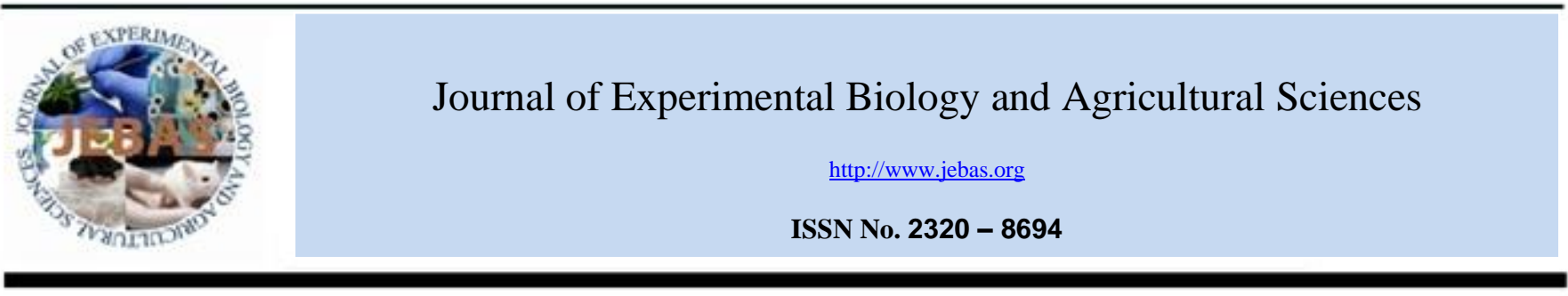

\title{
EFFECT OF NITROGEN LEVEL, GREEN AND ANIMAL MANURE ON THE GROWTH ATTRIBUTE OF CORN CROP (Zea mays L.)
}

\section{Khashayar Zakikhani, Ali Kashani* and Farzad Paknejad}

Department of Agronomy, Karaj Branch, Islamic Azad University, Karaj, Iran

Received - April 01, 2016; Revision - April 22, 2016; Accepted - May 13, 2016

Available Online - May 13, 2016

DOI: http://dx.doi.org/10.18006/2016.4(2).225.231

\begin{abstract}
KEYWORDS
Nitrogen

Fertilizer

Protein

Green Manure

Cover crops

ABSTRACT

This study was to conducted to evaluate the effects of individual or combined application chemical nitrogen fertilizer, green and animal manure on the various growth attributes such as number of seeds, weight of 1000 grains, grain yield, biomass and total grain protein in Single Cross hybrid (S.C 704) in maize. This experiment was conducted in 2014 at the Agricultural Research Station of Islamic Azad University of Karaj, Iran. The study was conducted in split plot factorial in a randomized complete block design with four replications. Results of the analysis of variance showed that the difference among grain number per cob among various treatments of cover crop levels at $1 \%$ and the effect of different amounts of animal manure at the 5\% level were significant, but there was no significant interaction among characters. But for other traits, the results of variance analysis table showed that the interaction of green manure and animal manure on 1000 grain weight at $5 \%$ and the nitrogen fertilizer on grain yield and biomass at 5\%, interaction of different levels of nitrogen fertilizer and green manure at $5 \%$ and the interaction of different amounts of nitrogen, green manure and animal manure on grain proteins at the level of $1 \%$ were significant.
\end{abstract}

* Corresponding author

E-mail: alro_kaschani@yahoo.de (Ali Kashani)

Peer review under responsibility of Journal of Experimental Biology and Agricultural Sciences.

Production and Hosting by Horizon Publisher India [HPI] (http://www.horizonpublisherindia.in/).

All rights reserved.
All the article published by Journal of Experimental Biology and Agricultural Sciences is licensed under a Creative Commons Attribution-NonCommercial 4.0 International License Based on a work at www.jebas.org.

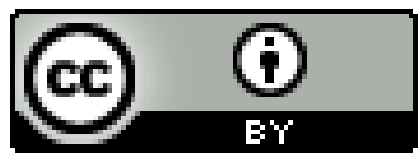




\section{Introduction}

Maize is one of the strategic crops because of its importance at human and animal nutrition and also broad compatibility with the temperate and tropical climate zones (Yazdani et al., 2009). Area under maize cultivation has been widely increased during past some decades; higher production of maize needs higher dose of nitrogen fertilizers. Excessive use of chemical substances, has led to increased production costs and environmental risks (Biari et al., 2008). Further, individual application of nitrogen has limited its efficiency because of its loss through denitrification, leaching and sublimation of ammonium. This loss not only reduced the efficiency of applied nitrogen but also responsible for the causes of environmental pollution. Increasing concerns about the harmful effect of the excess use of chemicals fertilizers such as nitrogen fertilizers pushed agricultural scientist and farmers to explore the alternate sources of chemical fertilizers. Organic sources of nitrogen can be serve a better option than the chemical fertilizers and can also play an important role in maintaining soil organic compounds and improve plant health (Ajvanzadeh, 2005; Kamkar \& Mahdavi damghani, 2006; Mahdavi Damqani et al., 2008; Ochiai et al., 2008;).

Now in these days, role of cover crops in improving soil characteristics, quality and preventing soil erosion are also well reported; these cover crops also play a significant role in the determination of weeds, pests and diseases. These plants not only enhance the soil organic matter but also reduced the dependency and consumption of chemical fertilizers and preventing environmental pollution (Hashemi et al., 2010).Therefore, pre-sowings of these green plants not only preserving the soil nitrogen but also adding nitrogen and carbon in agricultural systems and improving $\mathrm{C} / \mathrm{N}$ ratio and preventing soil erosion. Three major groups of plants, including grasses, legumes and Brassica are used as green manure. Among these Brassica is considered as most suitable replacement for legumes and grasses to cultivate and in addition to the effect of green manure can significantly increase soil organic carbon and soil porosity (Collins et al., 2007).

Use of these cover crops not only increase production but also reduced the risk associated with the modern crop production. Further, it also showing superiority over the biofertilizers and avoid the limitation associated with the use of biofertilizers and and chemical fertilizers. Among varieties of organic fertilizers, green manure has high importance because of economic and environmental issues; the use of pre-cultured plants of Perko can be considered as a green manure for maize (Baghdadi et al., 2016). Perko is an annual plant with wide and curved leaves which are connected by thick petiole to the growing point near the crown and the ground. This plant is a hybrid and artificially tetraploid which was produced by the crossing between winter rapeseed (with 19 pairs of chromosomes) and Chinese cabbage (with 10 pairs of chromosomes) (Kashani et al., 1986).
Like green manures, animals manures is also an important sources of nitrogen and provide nutrition to the growing crops (Kaveh Firooz et al., 2013; Baghdadi et al., 2016). Animal manure also reduced environmental risk and excess use of chemical fertilizers. Although, individually use of these manure work as an soil supplement but its combination with green manure and chemical fertilizers shows synergetic effect and not only increase crop production but also reduced the dose of chemical fertilizers. Further, these combinations can increase the production efficiency in addition to cost savings. Therefore, present study was under taken to explore the potential of the use of nitrogen fertilizers, green manure and animal manure, synergistically and to decide the right combination which leads to the best efficiency in improving the quantitative and qualitative yield of maize crops.

\section{Materials and Methods}

This experiment was conducted in 2014 at the Agricultural Research Station of Islamic Azad University of Karaj, Iran. The study was conducted in split plot factorial in a randomized complete block design with four replications. The main treatments consisted of nitrogen (at three levels of 120, 240 and $360 \mathrm{~kg}$ of urea) and green manure (Perko). Subsidiary treatment involved the animal manure ( 25 tons per hectare). Nitrogen and green manure were placed in main plots and animal manure was used in subplots. Dimensions of subplots were considered as $6 / 21$ square meters $(3.6 \times 6 \mathrm{~m})$ with 5 lines and the distance between the main plots were 3 meters as well as distance between repetitions was taken 4 meters. Precultured Perko plants were planted in the middle of March and were returned to ground on late May. Pre-cultured planting irrigation was performed by flooding method and the operations of maize planting was carried out 14 days after the returning the pre-cultured Perko plant to the soil. For planting the maize plant, after reviewing the available varieties of the studied region, Single Cross maize cultivars SC 704 was selected for this study. This variety is a serotinous hybrid and has optimal yield in a wide range of weather conditions. Maize planting was carried out in the middle of July and the harvesting was performed on October in 2014. The lines distance for planting was $65 \mathrm{~cm}$ with a density of 8 plants per square meter in plots with a size of 16 square meters.

Selected cover crop was Perko belongs to family Brassicaceae and are widely cultivated in temperate areas of Europe (Kashani et al., 1986). In this study, the effect of cover crop, different levels of nitrogen and animal manure was evaluated on yield and components of maize. The planting, harvesting, and sampling required during the life cycle of the maize plants were continuously carried out. In this experiment, the numbers of seeds, weight of 1000 grain, grain yield and protein content (\%) were determined. Protein content was measured by infrared spectroscopy (NIR). 
Table 1 The Physico-chemical properties of the study area soil samples.

\begin{tabular}{|cccccccccc|} 
characteristics & $\begin{array}{c}\text { sampling } \\
\text { depth }\end{array}$ & $\begin{array}{c}\text { salinity } \\
\text { Ds/m }\end{array}$ & $\mathrm{pH}$ & $\begin{array}{c}\text { Lime } \\
\%\end{array}$ & $\begin{array}{c}\text { organic } \\
\text { carbon } \%\end{array}$ & $\begin{array}{c}\text { Nitrogen } \\
\%\end{array}$ & $\begin{array}{c}\text { Phosphorus } \\
\text { ppm }\end{array}$ & $\begin{array}{c}\text { Potassium } \\
\text { ppm }\end{array}$ & tissue \\
\hline & $0-30$ & 5.81 & 8.35 & 15.08 & 1.28 & 0.13 & 22.23 & 342.7 & Clay Loam \\
\hline
\end{tabular}

Statistical analysis were performed using the software SAS and Duncan's multiple range tests were used to compare means at the probability level of $5 \%$.

\subsection{Physical and chemical properties of the soil}

To determine the physical and chemical properties of soil at the site of the experiment, 20 soil samples were randomly taken from $0-30 \mathrm{~cm}$ depth for each experimental and culture conditions. Then samples were carefully mixed together and turned into a single sample and were transferred to the laboratory; its characteristics have been shown in table 1 . Chemical analysis of the collected soil samples was carried out by the method described by Hesse (1971). Soil salinity measurements were performed by EC meter.

\section{Results and Discussion}

\subsection{The number of seeds per cob}

Result of study reported that the number of seeds per cob was significant at $\mathrm{P} \leq 0.01$ probability level in the treatment containing green manure (Table 2 ). The maximum number was 389.33 under green manure treatment and the lowest number reduced to 269.38 at the time of non-use of green manure (Figure 1). The significant effect of different amounts of animal manures on this number was also observed at the $\mathrm{P} \leq$ 0.05 probability level (Table 2). According to mean comparisons for the traits using Duncan's method, maximum number was obtained 351.41 in animal manure treatment and the minimum was 307.30 in the absence of manure (Figure 2). Results of this study are in agreement with the findings of Zadabdullah (2012) those who reported significant improvement in the grain per cob on the application of green manure. Similarly, Yazdani et al. (2009) reported that the application of animal manure increased the number of grain per pod and it showed superiority over the chemical nitrogen fertilizers.

\subsection{Weight of 1000 maize seeds}

Effect of various fertilizers on weight of 1000 seed was reported in this study and revealed that treatments containing nitrogen fertilizers shows difference at the probability level of $1 \%$ ( $\mathrm{P} \leq 0.01$ Table 2$)$ while in case of various manures interaction this significant difference was reported on the probability level 5 percent $(\mathrm{P} \leq 0.05)$. Among various tested combination highest seed weight $(230.63 \mathrm{~g} / 1000$ seeds) was reported in the treatment containing highest dose $(360 \mathrm{Kg} / \mathrm{ha})$ of chemical nitrogen fertilizer urea which suggested that the seed weight was increased with the increasing the value of nitrogen fertilizers and while the least weight $(153.95 \mathrm{~g} / 1000$ seeds) was reported from treatment containing lowest amount of nitrogen fertilizer $(120 \mathrm{~kg} / \mathrm{ha} \mathrm{N})$. Furthermore, individual application of animal manure also showed poor performance and are not significantly differ from the lowest level of nitrogen fertilizer (Figure 3). Although individual application of green manure shows superiority over the lowest level of nitrogen and animal manure but it performed poorly as compared to interaction.

Among various combinations, highest weight of 1000 seeds was reported from the interaction of green manure, animal manure and lowest dose of nitrogen fertilizers $(224.66 \mathrm{~g} / 1000$ seeds) and it was almost at par to the highest dose of nitrogen fertilizers while this weight was immediately followed by the interaction of green and animal manures $(201.10 \mathrm{~g} / 1000$ seeds).

Table 2 Variance analysis of main and interaction effects of traits

\begin{tabular}{|c|c|c|c|c|c|c|}
\hline $\begin{array}{l}\text { Source of variations } \\
\text { S.O.V. }\end{array}$ & $\begin{array}{c}\text { Degree of Freedom } \\
\text { d.f. }\end{array}$ & Grain No. in cob & $\begin{array}{l}1000 \text { grain } \\
\text { weight }\end{array}$ & Grain yield & $\begin{array}{l}\text { Biological } \\
\text { yield }\end{array}$ & $\begin{array}{l}\text { Grain } \\
\text { protein }\end{array}$ \\
\hline Replication & 3 & $1226.44^{\mathrm{ns}}$ & $304.64^{\mathrm{ns}}$ & $141652.05^{\mathrm{ns}}$ & $12.07^{\mathrm{ns}}$ & $2.17^{\mathrm{ns}}$ \\
\hline Nitrogen $(\mathrm{N})$ & 2 & $1112.99^{\mathrm{ns}}$ & $1710.62^{* *}$ & $9191109.19^{*}$ & $24.88^{*}$ & $1.20^{\mathrm{ns}}$ \\
\hline Green manure $(\mathrm{Gn})$ & 1 & $172662.03^{* *}$ & $986.36^{\mathrm{ns}}$ & $1055065.57^{\mathrm{ns}}$ & $2.95^{\mathrm{ns}}$ & $7.85^{*}$ \\
\hline $\mathrm{N} \times \mathrm{Gn}$ & 2 & $1501.84^{\mathrm{ns}}$ & $593.62^{\mathrm{ns}}$ & $1497759.56^{*}$ & $54.85^{* *}$ & $0.64^{\mathrm{ns}}$ \\
\hline Error $\mathrm{N} \times \mathrm{Gn}$ & 9 & 6801.09 & 443.09 & 32226.62 & 5.93 & 0.83 \\
\hline Animal manure (An) & 1 & $23352.27^{*}$ & $882.45^{\mathrm{ns}}$ & $772668.62^{\mathrm{ns}}$ & $46.21^{*}$ & $3.86^{*}$ \\
\hline $\mathrm{N} \times \mathrm{An}$ & 2 & $577.50^{\text {ns }}$ & $109.20^{\mathrm{ns}}$ & $37922.73^{\mathrm{ns}}$ & $3.28^{\mathrm{ns}}$ & $0.82^{\mathrm{ns}}$ \\
\hline $\mathrm{Gn} \times \mathrm{An}$ & 1 & $226.85^{\mathrm{ns}}$ & $2589.70^{* * *}$ & $922410.88^{\mathrm{ns}}$ & $40.88^{*}$ & $0.09^{\mathrm{ns}}$ \\
\hline $\mathrm{N} \times \mathrm{Gn} \times \mathrm{An}$ & 2 & $2255.03^{\mathrm{ns}}$ & $280.35^{\mathrm{ns}}$ & $276572.20^{\mathrm{ns}}$ & $13.72^{\mathrm{ns}}$ & $2.53^{* * *}$ \\
\hline Error & 18 & 4332.10 & 290.70 & 649811.29 & 6.06 & 0.54 \\
\hline C.V. (\%) & & 14.98 & 11.38 & 13.58 & 15.03 & 8 \\
\hline
\end{tabular}

n.s: not significant. *, **: Statistically significant at $\mathrm{P}<0.05,0.01$, respectively. 


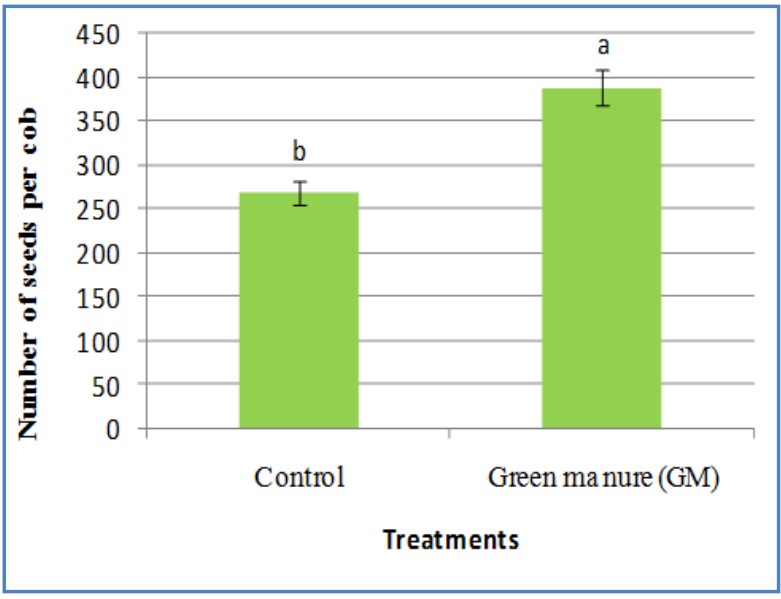

Figure 1 The effect of green manure on the number of seeds per cob.

The results correspond with the results of Kaveh Firooz et al. (2013) those have reported that the increase in soil organic matters with a combination of animal manure and green manure increased thousand seed weight and finally the yield. Generally, there is a positive relationship between the soil biomass and size of plant in maize grain and grain Number and it increase with the increasing levels of green and organic material (Zadabdullah, 2012). Result of study revealed that application of green and animal manures reduced the dependency on the chemical fertilizers and it can be helpful in reducing the cost of production.

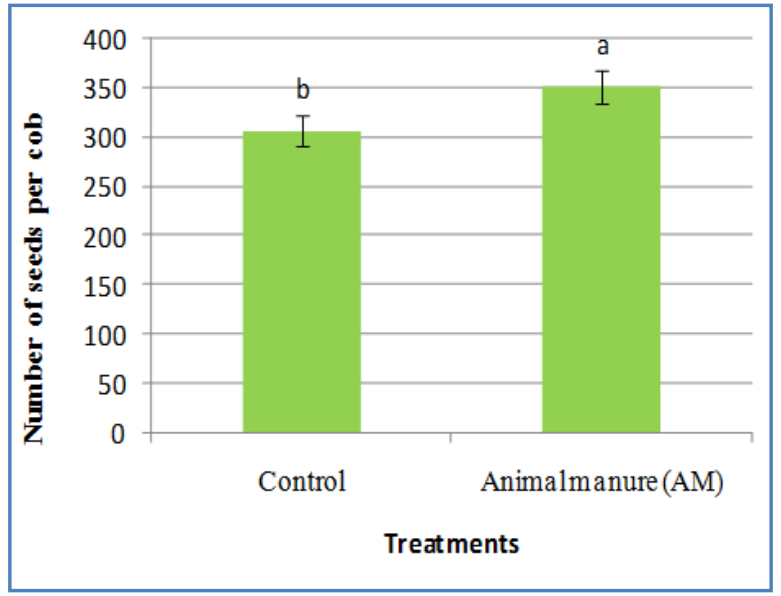

Figure 2 The effect of animal manure on the number of seeds per cob.

\subsection{Grain yield}

Results of grain yield study shows similarities with the results of 1000 seeds and it was reported highest $(6227.58 \mathrm{~kg} / \mathrm{ha})$ in the treatment containing $360 \mathrm{~kg} / \mathrm{ha} \mathrm{N}$ ha while the lowest $(4863.40 \mathrm{~kg} / \mathrm{ha})$ was reported in the treatment containing least nitrogen fertilizer $120 \mathrm{~kg} / \mathrm{ha}$ nitrogen (Figure 4). Interaction effect between green manure and nitrogen fertilizer on seed yield was significant at $5 \%$ probability level $(\mathrm{P} \leq 0.05)$ (Table 2).

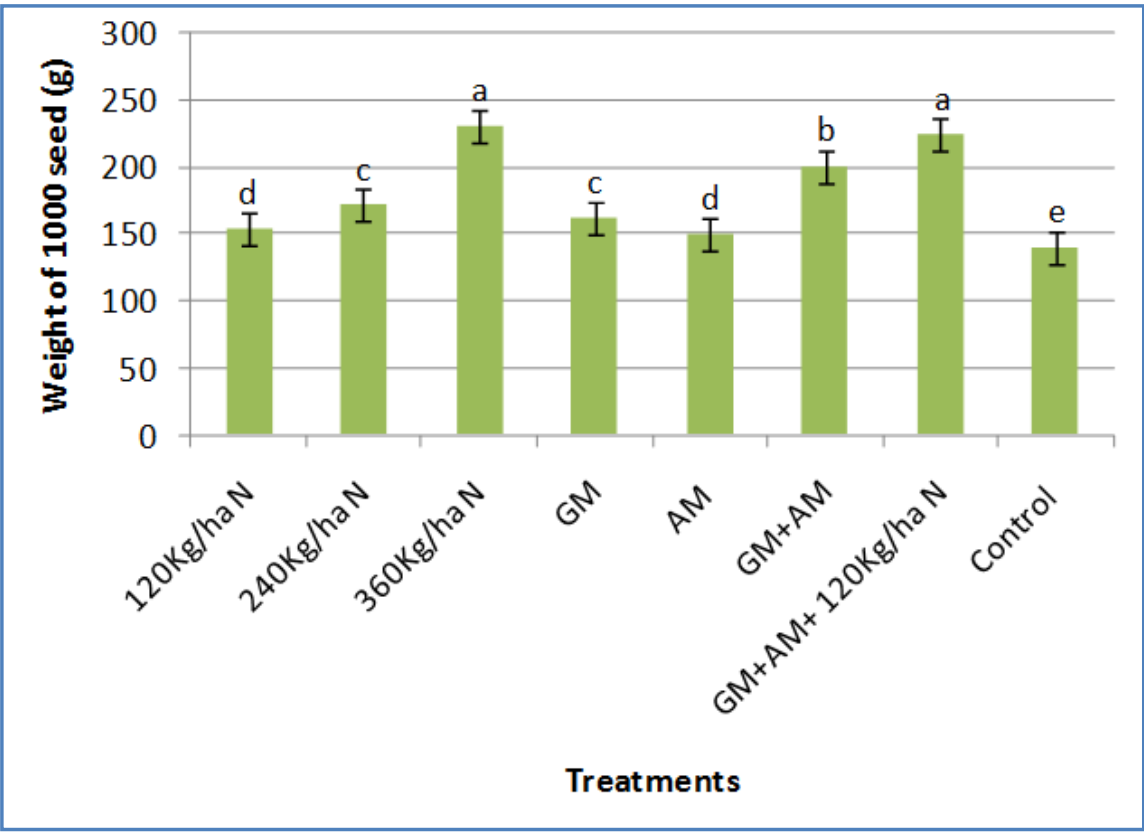

Figure 3 Effect of various treatments on the weight of 1000 seeds; values without common letter differ significantly $(\mathrm{P} \leq 0.05)$ as per LSD test 


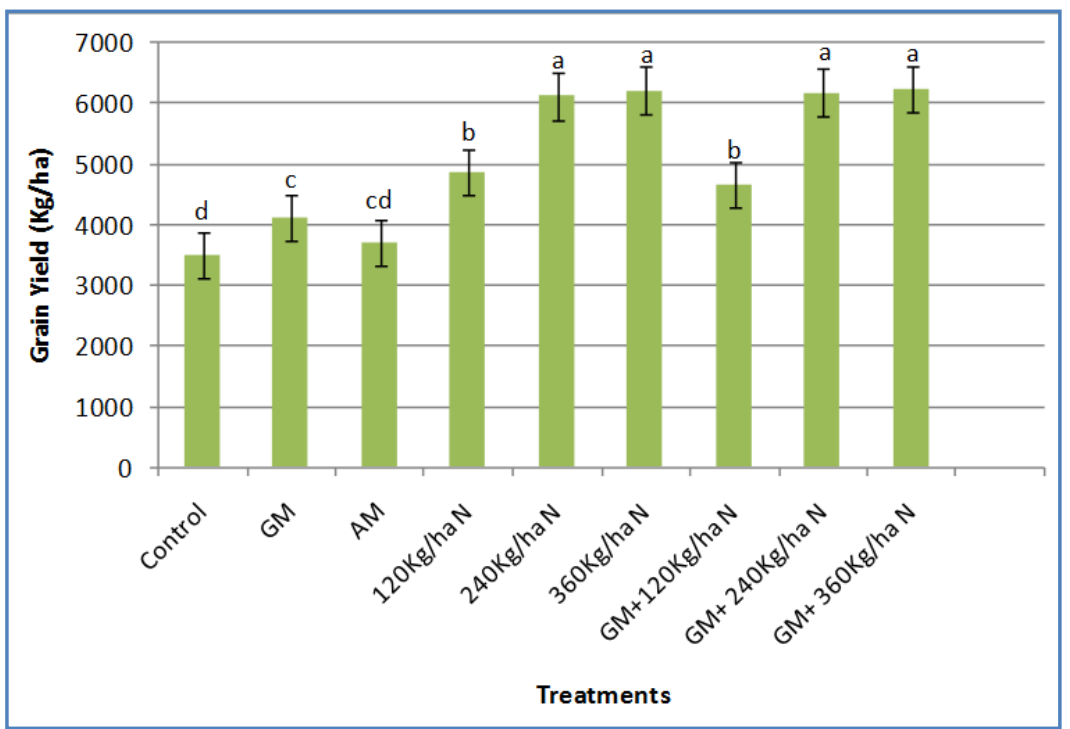

Figure 4 Effect of individual and combined application of nitrogen fertilizer and green manures on the grain yield; ; values without common letter differ significantly $(\mathrm{P} \leq 0.05)$ as per LSD test.

In interaction study, maximum yield $(6351.55 \mathrm{~kg} / \mathrm{ha})$ was reported from combination of green manure and $360 \mathrm{~kg} / \mathrm{ha}$ nitrogen and it was followed $(6251.55 \mathrm{~kg} / \mathrm{ha})$ by the combination of green manure and $240 \mathrm{~kg} / \mathrm{ha}$ nitrogen results, these two treatments are not significantly differ from each other.

Least effective combination was green manure and $120 \mathrm{~kg} / \mathrm{ha}$ nitrogen combination and it resulted only $4658.77 \mathrm{k} / \mathrm{ha}$ grain yield (Figure 4). Individual and combined application of animal manure are not showing significant difference from individual application of nitrogen fertilizers or green manures, that's why these treatment was not reported in the figures. The results were consistent with the findings of Baghdadi et al (2016), Kaveh Firooz et al. (2013) and Adesoji et al. (2013). The researchers reported that the grain yield increased in maize due to increasing nitrogen levels and use of organic fertilizers.

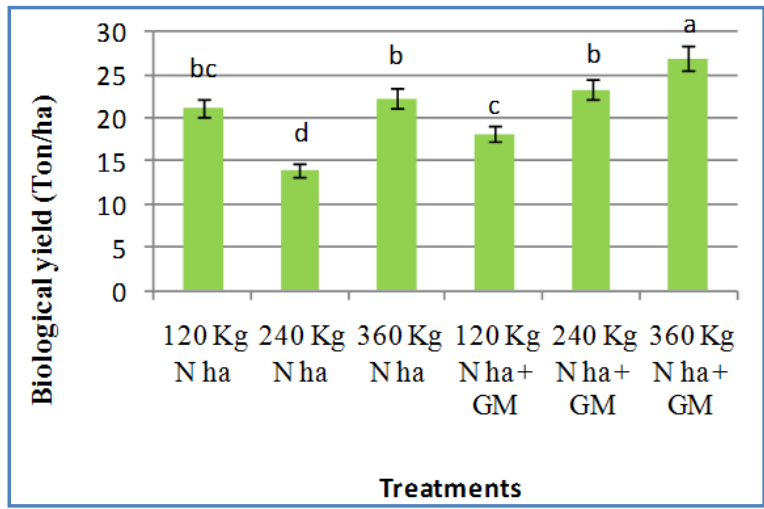

Figure 5 Interactions of nitrogen fertilizer and green manure on Maize Biomass; values without common letter differ significantly $(\mathrm{P} \leq 0.05)$ as per LSD test
Grain yield study also suggested the reduction in the dependency chemical fertilizers.

\subsection{Effect of various combinations on Biomass of crops}

Green manure and nitrogen fertilizer interactions were significant at the $5 \%$ level on biomass. Highest (23.34 t/ha) and lowest (18.2 t/ha) biomass was reported from the treatments containing green manure along with $240 \mathrm{Kg} / \mathrm{ha}$ and $120 \mathrm{Kg} / \mathrm{ha}$ nitrogen respectively (Figure 5). The combined effect of green and animal manures on biological yield was significant at the 5\% level. Green manure along with animal manure treatments had the greatest biomass about $25.66 \mathrm{t} / \mathrm{ha}$ and the least rate was $18.04 \mathrm{t} / \mathrm{ha}$ in the absence of both manures (Figure 6). Results of present study are in agreement with the findings of the Baghdadi et al. (2016).

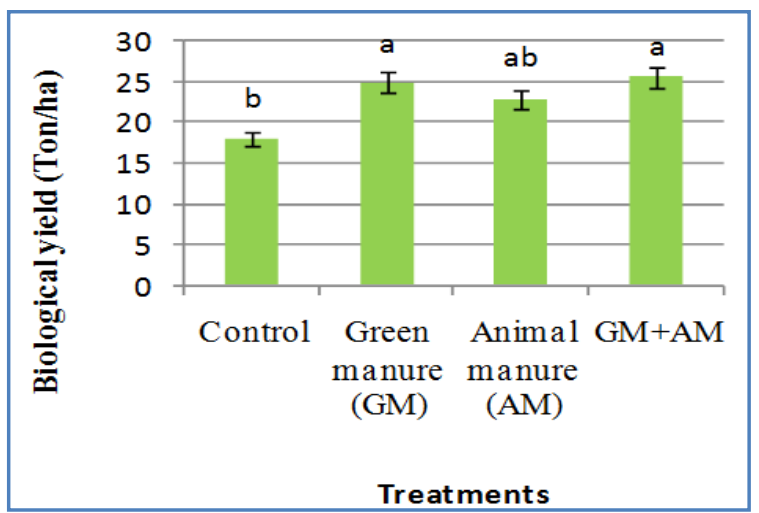

Figure 6 Effect of animal and green manure on Maize

Biomass; values without common letter differ significantly $(\mathrm{P} \leq 0.05)$ as per LSD test 


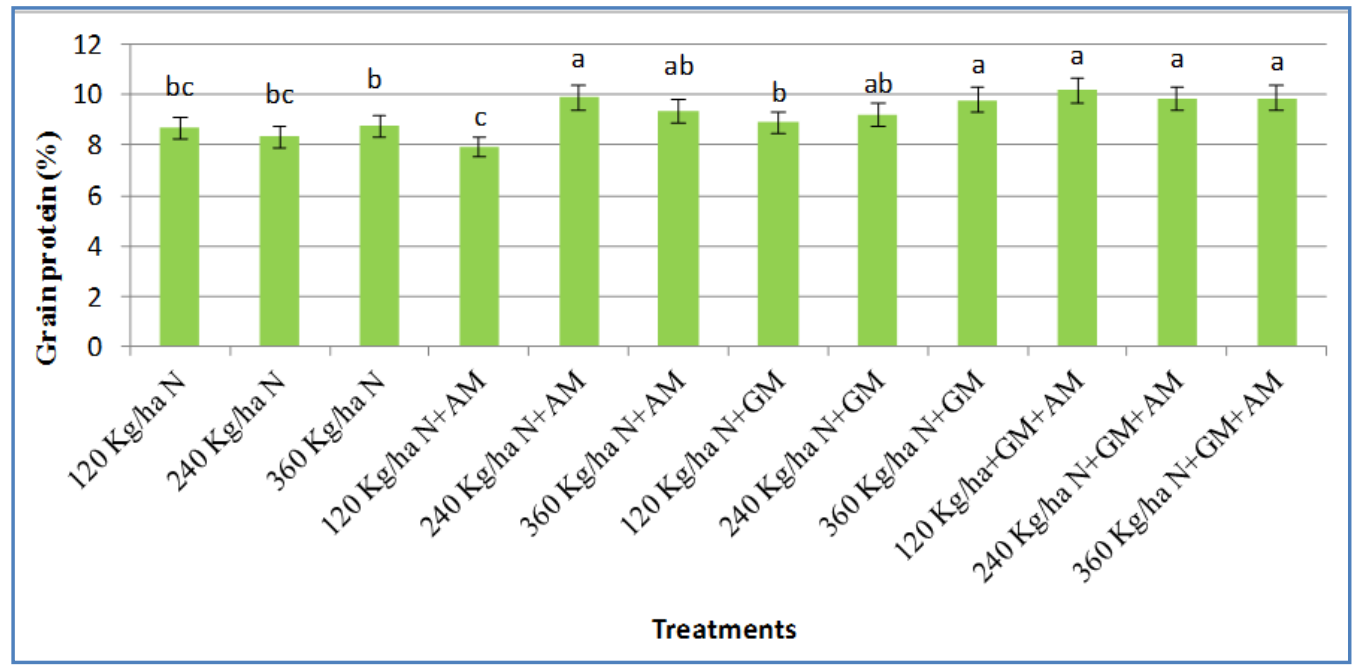

Figure 5 Interactions of animal manure, green manure and various amounts of nitrogen on maize grain protein.

\subsection{Grain protein}

Results of variance analysis revealed that the interaction of the three parameters including nitrogen fertilizers, green manure and animal manure on grain protein was significant at $1 \%$ probability level (Table 2). Based on the table the highest average grain protein content was $10.17 \%$ in the treatments using green and animal manures with $120 \mathrm{~kg} \mathrm{~N}$ ha and the lowest content was observed $7.95 \%$ in treatments with the use of animal manure and $120 \mathrm{~kg} \mathrm{~N}$ ha without green manure (Figure 7). The results were aligned with the findings of Campbell \& Akhtar (1990); Tripolskaya \& Romanovskaya (2006) and Talger et al. (2009).

\section{Conclusion}

Evaluation of the overall results of this study suggested that use of green manure and animal manure not only reduced the risks of chemical fertilizers but also increased crop production, grain yield and protein contents of maize grain. The most important sources of soil organic matters include livestock waste, plant residues and composts obtained from municipal garbage which today considering to the importance of organic farming, their use has been greatly considered. It was also reported that individual application of manure or chemical fertilizers cannot solve all the nutritional requirements of plants, therefore combination of these fertilizers and proper management in the use of amount, the time and way of using these fertilizers could have the best impact on productivity.

\section{Conflict of Interest}

Authors would hereby like to declare that there is no conflict of interests that could possibly arise.

\section{References}

Adesoji AG, Abubakar IU, Tanimu B, Labe DA (2013) Influence of Incorporated short duration legume fallow and nitrogen on maize (Zea mays L.) growth and development in northern guinea savannah of Nigeria. American-Eurasian Journal Agricultural Environment Science 13: 58-67. DOI: 10.5829/idosi.aejaes.2013.13.01.1885.

Ajvanzadeh M (2005) Effects of organic materials with different levels of quality and the physicochemical properties of soil and potato yield. Ph.D. thesis submitted to University of Zanjan, Iran, Pp. 30-37 (In Persian).

Baghdadi A, Kashani A, Vazan S (2016) The effect of presowing treatments and nitrogen rates on yield of silage maize (Zea mays L.) SC 704. International Journal of Advanced Life Sciences 9: 10-18.

Biari A, Gholami A, Rahmani HA (2008) Growth promotion and enhanced nutrient uptake of maize by application of plant growth promoting rhizobacteria in arid region of Iran. Journal Biological Science 8: 1015-1020. DOI: 10.3923/jbs.2008.1015.1020.

Campbell JA, Akhtar ME (1990) Impact of tillage on soil water regimes in the rainfed areas of Pakistan. Soil Physics 267-275.

Collins HP, Delgado JA, Alva AK, Follett RF (2007) Use of Nitrogen-15 Isotopic Techniques to Estimate Nitrogen Cycling from a Mustard Cover Crop to Potatoes. Agronomy Journals 99 : 27-35. doi:10.2134/agronj2005.0357. 
Hashemi M, Farsad A, Herbert SJ (2010) Managing cover crop for maximum nutrient recovery. Environmental Science Research Institute, Shahid Beheshti University, Tehran., 248254. (In Persian)

Hesse PR (1971). A Text Book of Soil Chemical Analysis. John Nurray Williams Clowes and sons Ltd. London, 324 pp.

Kamkar B, Mahdavi Damghani A (2006) Principles of sustainable agriculture. First Edition. Publications University of Mashhad, Iran., 62-74. (In Persian)

Kashani A, Bohrani J, Alemi Said Kh, Mesgarbashi M (1986) Scientific Report of introduction of three varieties of forage plants in the genus Brassica and report the results of their preliminary research in Khuzestan. Journal of Agriculture 11: 74-78. (In Persian)

Kaveh Firooz M, Kashani A, Paknejad F, Vazan S (2013) Effects of pre-sowing and nitrogen fertilizer levels on qualitative and quantitative characteristics of 640 corn varieties. M. Sc. thesis submitted to Islamic Azad University of Karaj, Iran, Pp.100-108. (In Persian)

Mahdavi Damqani A, Koocheki A, Rezvani Moqaddam P, Nassiri Mahallati M (2006) Studying the sustainability of a wheat-cotton agroecosystem in Iran. Asian Journal of Plant Sciences 5: 559-562. DOI: 10.3923/ajps.2006.559.562.

Ochiai N, Powelson ML, Crowe FJ, Dick RP (2008) Green manure effects on soil quality in relation to suppression of Verticillium wilt of potatoes. Biology and Fertility of Soils 44: 1013-1023. DOI: 10.1007/s00374-008-0289-z.

Talger L, Lauringson E, Roostalu H, Astover A (2009) The effects of green manures on yields and yield quality of spring wheat. Agronomy Research 7:125-132.

Tripolskaya L, Romanovskaya D (2006) A study of nitrogen migration affected by different plants for green manure in sandy loam soil. Ekologija 4: 89-97.

Yazdani M, Bahmanyar MA, Pirdashti H, Esmaili MA (2009) Effect of Phosphate Solubilization Microorganisms (PSM) and Plant Growth Promoting Rhizobacteria (PGPR) on Yield and Yield Components of Corn (Zea mays L.). International Journal of Biological, Biomolecular, Agricultural, Food and Biotechnological Engineering 3:50-52.

Zadabdullah M, Vazan S, Kashani A (2014) Effects of Nitrogen Fertilizer on cover crops and weed control and crop yield in Tehran. Ms.C. thesis submitted to Islamic Azad University of Karaj, Iran. 85-96. (In Persian) 